\title{
Advantages of implementing mediamorphosis in supporting Using-ethnic programs at Radio Sritanjung FM Banyuwangi
}

\section{Keuntungan penerapan mediamorfosis dalam mendukung siaran program etnis Using di Radio Sritanjung FM Banyuwangi}

\author{
Zainal Abidin Achmad ${ }^{1 *}$, Juwito Juwito', Yuli Candrasari', \& Asia Ashfaq ${ }^{2}$ \\ ${ }^{1}$ Department of Communication Science, Faculty of Social Sciences and Political Sciences, \\ Universitas Pembangunan Nasional "Veteran" Jawa Timur \\ ${ }^{2}$ Department of Humanities and Social Sciences, Bahria University Islamabad \\ Address: ' Jalan Rungkut Madya, Gunung Anyar, Surabaya, East Java, Indonesia 60294 \\ ${ }^{2}$ Shangrilla Road, Sector E-8, Islamabad, Pakistan \\ E-mail: z.abidinachmad@upnjatim.ac.id
}

Article History: Received 10 October 2020; Accepted 9 April 2021; Published Online 19 April 2021

\begin{abstract}
Many private radio businesses have experienced a decline in advertising revenue during the COVID-19 pandemic, however, this did not happen to Radio Sritanjung FM Banyuwangi, which implemented mediamorphosis to support its broadcasts. This study aims to map the application of mediamorphosis in supporting the broadcast of cultural programs on Radio Sritanjung FM, Banyuwangi, East Java, Indonesia. This study used a qualitative virtual ethnographic method, which requires researchers to enter two research areas: the natural world and the virtual world. Researchers interacted freely with eight informants, such as Using-ethnic figures, Muslim leaders, radio station management, local advertisers, and loyal listeners through in-depth interviews and Focus Group Discussions (FGD) to understand the ongoing mediamorphosis process in a virtual network. The research analysis using network society theory shows that the mediamorphosis process of Radio Sritanjung FM began in 2011 with Facebook, Instagram, and Twitter. The latest technology application is audio streaming to support, promote, and disseminate the Using's ethnic culture to foreign countries. The application of mediamorphosis during the COVID-19 pandemic presents a harmonization between cultural programs and Islamic religious values, strengthening the local identity of the Using-ethnicity, and increases financial benefits.
\end{abstract}

Keywords: mediamorphosis; network society; radio culture; virtual ethnography

\begin{abstract}
Abstrak
Banyak bisnis radio swasta yang mengalami penurunan pendapatan iklan selama masa pandemi COVID-19, tetapi hal tersebut tidak terjadi pada Radio Sritanjung FM Banyuwangi yang menerapkan mediamorfosis untuk mendukung siarannya. Penelitian ini bertujuan untuk memetakan penerapan mediamorfosis dalam mendukung siaran program budaya di Radio Sritanjung FM, Banyuwangi, Jawa Timur, Indonesia. Penelitian ini menggunakan metode kualitatif etnografi virtual, yang menuntut peneliti untuk memasuki dua wilayah penelitian yaitu, dunia nyata dan virtual. Peneliti dapat berinteraksi secara leluasa dengan delapan orang informan, yaitu tokoh etnis Using, tokoh agama Islam, manajemen radio, pengiklan lokal, dan pendengar loyal melalui wawancara mendalam dan diskusi kelompok terarah untuk memahami proses mediamorfosis yang sedang berlangsung dalam jaringan virtual. Analisis penelitian dengan menggunakan teori masyarakat jaringan, mendapatkan hasil bahwa proses mediamorphosis Radio Sritanjung FM dimulai sejak tahun 2011 dengan menggunakan Facebook, Instagram, dan twitter. Teknologi yang terbaru adalah audio streaming untuk mendukung, mempromosikan dan menyebarluaskan budaya etnis Using hingga mancanegara. Penerapan mediamorphosis selama masa pandemi COVID-19 di Radio Sritanjung FM mampu menyajikan harmonisasi antara progam budaya dengan nilai-nilai religius Islam, memperkuat identitas lokal etnis Using, dan meningkatkan keuntungan finansial.
\end{abstract}

Kata kunci: mediamorphosis; masyarakat jaringan; radio budaya; etnografi virtual

\section{Introduction}

Admittedly, the COVID-19 pandemic situation has seriously affected the radio industry. Many private broadcast radio stations have to find ways to survive, including simplifying programs, reducing the number of employees, reducing live broadcast hours, increasing the recorded broadcasts, and reducing 
the cost of using technology. The adaptation to the COVID-19 pandemic has stymied many radio owners and creative professionals. Interestingly, a pandemic situation like this is a situation that tests radio broadcasts' resilience through social media platforms on the internet. The broadcasting process has evolved to be more creative and collaborative (Achmad et al. 2020b).

While some private broadcast radio stations recalculated technology by deactivating some of their social media, some cultural radio stations increased their utilization. One of them was Radio Sritanjung FM in Banyuwangi. For Radio Sritanjung FM management, the present COVID-19 pandemic did not mean stopping working and trying, however an opportunity for more development. Logically, the pandemic conditions caused people to increase time spent on the internet (Achmad et al. 2021). When communication technology develops, it presents conditions for the formation of organizational networks in social structures. Castells (2010) refers to this condition as pervasiveness when technology has become an integral part of technology users' lives and environment.

Various research shows that successful private broadcast radio stations benefit from many advertisements (Ferguson 2007, Kimms \& Muller-Bungart 2007, Hadadi \& Almsafir 2013, Jaekel 2017, Halbrooks 2018, Morello 2019). There are many other supporting factors, namely: good broadcast programs, large numbers of listeners, the creativity of program producers, advances in broadcast technology, loyal and interactive listeners, conducive socio-political conditions, and reliable management (Tjahjo 2012, Alamiyah \& Achmad 2015, Achmad \& Ida 2018, 2019, Achmad 2019). In the contemporary context, a factor often considered is the support for applying communication technology with online platforms through the internet (Commercial Radio Australia 2004, Ofcom 2006, Pandey et al. 2017, Lee et al. 2018).

Another advantage of using communication technology to support radio broadcasts is cultural inheritance and strengthening local identities. Radio broadcasts using local cultural identities (language and local traditional arts) are the hallmarks of cultural radio programs (Bosch 2014). Radio Sritanjung FM developed a different way of broadcasting, in the landscape of today's digital life, by utilizing various web-based communication platforms as channels for delivering broadcast content (May 2013). Advances in communication technology have brought the distance between media producers and their audiences even closer (Benkler 2006). The internet and various social networking applications provide a technology platform that changes the relationship between radio institutions and their listeners. The most significant change in the world of radio is the characteristics of its listeners. In the past, radio listeners were passive and maintained their privacy; now, they emerge as public actors and networks (Bonini 2014).

Radio Sritanjung FM's existence as a cultural radio station explains the strained local culture position between popular cultures. Among the private broadcast radio stations that use cultural identities is Radio Sritanjung FM with the slogan "Radioe Lare Using" (the radio that belongs to Using-ethnic people), which has changed to "Kebanggaan Banyuwangi" (the pride of Banyuwangi people). Determining positioning as a radio culture using a specific segmentation is an intelligent strategy to face intense competition (Rothenbuhler 1996, Warren 2005, Alamiyah \& Achmad 2015). For listeners and advertisers to like broadcast programs, segmentation must be specific, and broadcast programming must adapt to the target audiencess character and culture (Walker 2004, Barber 2010). Radio Sritanjung FM received stable financial benefits from advertising (mostly from local advertisers).

Especially in the period leading up to the regional head elections, Radio Sritanjung FM received many political advertisement requests. Furthermore, those parties' involvement is getting more intense (interview with LH). The political competition leading up to the December 2020 regional elections was a significant income source for Radio Sritanjung FM. In a pandemic situation, the choice to advertise on the radio is a rational choice. Newspapers were no longer the choice for political advertising. The number of newspaper sales dropped dramatically due to public concerns about holding paper-based newspapers as a medium for spreading the COVID-19 virus. Meanwhile, although significant, political advertising 
on television is expensive (Shauma \& Achmad 2015). The most influential political advertising media during the COVID-19 pandemic was the radio and outdoor media, such as billboards and banners (International IDEA 2020).

Apart from having the advantage of solid positioning and proximity of broadcast content to local culture, Radio Sritanjung FM continued to maintain interaction with loyal listeners (Mytton 1992, Nguyen 2008, King 2015, Wilkinson 2015). Radio Sritanjung FM established itself as a medium that reduces the distance between broadcasters and listeners. It provided opportunities for parties (cultural figures, religious leaders, journalists, local advertisers, copywriters, programmers, broadcasters, and listeners) to play producers for some of their broadcast programs. This study aims to map the application of mediamorphosis in supporting the broadcast of cultural programs on Radio Sritanjung FM.

The development of communication media has a mutual influence on human culture development (Nwammuo 2011). New forms of communication media with new implementation methods are evolving the media present before as the foundation of mediamorphosis (Fidler 1997). Mediamorphosis is not just a transformation of the form of communication media; however, it is a unified way of thinking about technological evolution in communication media. As a scientific term, mediamorphosis (which comes from two words: media and morphosis) explains the media world's simultaneous changes (Biagi 2017, Achmad 2020a). The evolution of media functions depends on the evolution of human life around it (McFadden 2012). The development of social culture affects the evolution of media functions. The strength of modernization has not been able to indistinct the traditional mass media and render it dysfunctional. The facts show that if humans still need the involvement of traditional mass media, they will exist. As many experts predict, traditional mass media will survive and adjust to the digital era's transition. History shows that old media and new media can coexist, and radio is the best example of this historical evidence (Sterling \& Kittross 2002).

Radio Sritanjung FM, through mediamorphosis, demonstrates the practice of changing the way of communicating to listeners. Radio listeners during the COVID-19 pandemic actively engaged as members of the network community, being present and actively communicating in various media on the internet. Listeners are increasingly present in radio broadcasts because they are part of program production as they are involved in designing and executing programs. The theory used to analyze the form of interaction and communication content in the internet network is the network society theory by Manuel Castells. Mediamorphosis makes Radio Sritanjung FM's passive listeners interactive, and they become radio program producers. Radio station digital presence allows listeners to live in the network by participating (comments, sharing, discussion) in radio programs. Radio listeners become part of the network community (Bonini 2014, Bonini \& Monclús 2015). The network society theory becomes a theory for analyzing data because, in a networked world system, traditional media (including radio) can no longer act alone as a source of information. Radio pervades and merges into the network, meaning that radio connects to the public apart from connecting. However, radio connection with the public lasts when the radio connects much information from nodes to other information networks (Bonini \& Monclús 2015). In an increasingly digital world, Radio Sritanjung FM listeners have shifted their role to become program producers. Radio listeners who sit and listen to broadcasts have become programmers and are involved in broadcasting (Gauntlett 2000).

The purpose of this study was to carry out a chronological exploration of the mediamorphosis process of Radio Sritanjung FM as a cultural radio station. It represents the identity of the Using-ethnicity by broadcasting extensive traditional music, the local language, and traditional drama to map the use of communication media technology, discover the benefits resulting from the application of mediamorphosis, and map out what cultural programs have increased due to mediamorphosis.

\section{Research Method}

The method used in this qualitative research was virtual ethnography. This method aims to provide an exceptional understanding of the significance and implications of using the internet in humans and trace human life when interacting with the internet (Hine 2000, 2008, 2017). The correct virtual 
ethnography method can provide the theoretical understanding and help determine the smooth dynamics of relationships in the online world (Hair \& Clark 2003, Shumar \& Madison 2013, Achmad \& Ida 2018). Data collection in this virtual ethnographic study used participant observation as an essential technique in examining networked community life and human presence on the internet (Myers 1987, Meyer \& Thomas 1990, Reid 1992, Rheingold 1995, Horn 1998, Kendall 1999, Sharf 1999, Turkle 2011). During participant observation, the researchers used in-depth interviews (online and offline) and focus group discussions on digging deeper into information. In-depth interviews are very suitable for virtual ethnographic research (Clandinin \& Connelly 2004, Hine 2005, Achmad 2019, Achmad \& Ida 2019).

This study chose the Radio Sritanjung FM station, located in the Rogojampi sub-District, Banyuwangi District. It has the most prolonged duration and most content of Using-ethnic cultural programs than other radio stations in Banyuwangi. It has the title of ethnic radio because it represents Using- ethnicity (PRSSNI 2018). The informants in the study amounted to eight people, consisting of J (Using-ethnic figure), LH (radio management), AY (Muslim leader), DA (broadcaster), DJ (local journalist), M (local advertiser), HO (loyal listener), and AS (loyal listener). Each informant was interviewed separately during August 2020 to explore their media habit, daily life connection to the internet, active participation with cultural programs, history of Banyuwangi, and socio-cultural surroundings. All informants were invited into Focus Group Discussions on 27 September 2020 to confirm and elaborate on the findings. The data analysis took place in three stages, the time before collecting data, while in the field (real and virtual), and after completing the field interviews. The data analysis strategy used grounded research. It continued to carry out data analysis by involving the mediamorphosis theory and the network society theory following the data collection process (Miles et al. 2014).

\section{Results and Discussion}

Radio Sritanjung FM officially began broadcasting in 1993 under the name of the late owner HY, a businessman and Madurese community leader in Banyuwangi whose thinking was often out of the box. HY owned Islamic religious education institutions (pesantren) and various other businesses (buying, selling, slaughtering cows, socio-religious foundations, Quran education park, Umrah, and Hajj guidance, and had a cooperative that financed small and medium enterprise). The decision to establish a private radio station was a breakthrough in business, difficult for many people to understand in Banyuwangi. The private radio business requires serious management and considerable initial investment, and many people knew the private radio business as a bad financial investment.

The initial purpose of establishing Radio Sritanjung FM was as a means of preaching Islam. According to HY, radio broadcasts can expand the impact of Islamic syi'ar (a manifestation of Islamic signs, symbols, slogans, and practices) and Islamic recitation. At that time, there was not a single radio in Banyuwangi broadcasting Islamic da'wah. Islamic syi'ar markers are only broadcasts of Maghrib call to prayer. Although HY did not understand radio licensing, he was determined to acquire a broadcast license by contacting many parties and acquaintances. One of them asked for a recommendation from the Brawijaya Military Commander, and the licensing process took up to two years. During the broadcast permit process, HY became acquainted with HRIH, the first Radio MTB FM owner in Surabaya. Because of their closeness as fellow Madurese, the two figures became friends and fought to acquire broadcast permits. H was the one who paved the way for the passage of the Radio Sritanjung FM license because one of the conditions for establishing a radio station at that time was a recommendation or approval from another radio station owner. By the time the transmitter tower was ready to operate, the Directorate General of Post and Telecommunication had not yet issued the license; however, Radio Sritanjung FM station had received permission from the governor to start official broadcasts.

HY was a very determined person, and Madurese people in Banyuwangi knew him from his distinctive and encouraging reputation. HY preferred to return to Madura if he failed to get a radio broadcast license. HY was embarrassed because he had succeeded in establishing a radio transmitter tower; however, he had not yet obtained a broadcast permit. This attitude shows the authoritarian character of the Madurese, 
who decided to migrate outside the island of Madura. The choice to return to Madura Island is a form of failure in the struggle for life. According to FGD, the purpose of establishing Radio Sritanjung FM as a medium for preaching Islam was to continue his legacy so that the merits of the syi'ar of Islamic charities would continue to flow even when HY had died.

The two friends collaborated in the initial management process of Radio Sritanjung FM, including structuring programs, recruiting broadcasters, producing advertisements, determining segments, and selecting music formats. The main difficulty in setting up a private radio station in the region is the limited human resources; finding broadcasters and programmers is very difficult. The most challenging consideration is deciding whether to be a $d a^{\prime}$ wah (preaching) radio or a music radio station. Positioning as a $d a$ ' wah radio will make it more difficult to get revenue from advertising because most advertisers put more money into entertainment programs. Therefore, listeners in Banyuwangi who are predominantly Muslim certainly do not like it because they need Islamic $d a$ 'wah broadcasts. Finally, HY combined his idealism for $d a$ ' wah through radio with his need to run the radio station as a business. The idealism of da'wah radio must be in line with the business orientation to continue Radio Sritanjung FM's development.

The decision to position Radio Sritanjung FM as an ethnic radio station was a first in East Java. The tagline "Sritanjung FM, Radio Etnik Banyuwangi" was chosen. A few years later, it changed to "Sritanjung FM, Radio Banyuwangi" and is currently "Sritanjung FM, Kebanggaan Banyuwangi." Nevertheless, the term "Radioe Lare Using" (the radio that belongs to Using-ethnic people) is always used to refer to Radio Sritanjung FM. Making Radio Sritanjung FM an ethnic radio station was the right choice for its future development. Determination of positioning as an ethnic radio station followed HLA as a Chairman of East Java Regional Administrators of Persatuan Radio Siaran Swasta Nasional Indonesia (hereafter called PRSSNI). Therefore, Radio Sritanjung FM has become close to the Using-ethnic community as the largest ethnic group in Banyuwangi. Since then, Radio Sritanjung FM has focused on developing broadcast programs in the Using, Javanese, and Madurese languages. The Madurese language broadcast was only able to last for two years because there were few listeners and no advertisers.

The combination of positioning Radio Sritanjung FM as an ethnic radio station and offering a selection of local segments has resulted in an extraordinary response. Every Saturday night, many listeners gather in the studio. These listeners organize themselves by forming a community according to the cultural broadcast program on Sritanjung FM. Two Sritanjung FM listening communities still survive today. First, the Rujak-Wuni Community, namely listeners from Javanese ethnicity, is like Javanese broadcasts. Second, the Geredoan Community, namely listeners who want Using broadcasts. Geredoan comes from the word nggridu, which in the Using language means teasing each other. In the relationship context, flirting has a positive meaning because geredoan generally takes good care of boys and girls to get a life partner. Geredoan is a local tradition to tempt the opposite sex, which leads to marriage (Mursidi \& Soetopo 2018, Wulandari 2018, Achmad et al. 2020b). According to HO and AS, the two communities regularly hold off-air events as a gathering place for listeners and management. Many meeting initiatives come from listeners. The activities are gathering, social service, discussion, eating, and karaoke.

The evidence that Radio Sritanjung FM in Banyuwangi is synonymous with ethnic radio is its involvement in over 90 cultural events spread throughout Banyuwangi Regency. According to DJ that under Regent Azwar Anas' leadership, Radio Sritanjung FM has partnered with the local government in every cultural event. The characteristic of the Banyuwangi people is that they love and are proud of Banyuwangi music. Therefore according to $J$ that the people of Banyuwangi find Radio Sritanjung FM the suitable medium to get information and Banyuwangian music.

Radio Sritanjung FM finds comfort in maintaining its identity as an ethnic radio station because it attempts to preserve its culture. It is also easier for businesses to market unique ethnic identities and local ethnic programs to advertisers. Because advertisers prefer media with specific audience segments, the market is exact, and the numbers are definite. Not surprisingly, Radio Sritanjung FM is very familiar 
to advertisers (especially local advertisers). According to $\mathrm{M}$, specific broadcast programs that support advertiser products cost at least 15 million IDR per month. If there is a request for support for off-air activities, the minimum price for a program is 50 million IDR.

A unique story took place during the establishment of Radio Sritanjung FM. Wanting to show that it was a big radio station, HY immediately recruited 20 employees. The goal was to imitate the number of radio crews owned by Radio Suzana FM Surabaya in a photo when he visited the PRSSNI East Java office. Then, HLA warned HY that if private radio has too many employees, it results in too small wages. Therefore, Radio Sritanjung FM had to reduce the number of employees immediately in order to reduce expenses. Meanwhile, Radio Suzana FM's profile photo, which had 30 employees, was only for promotional media. The actual number of permanent employees is only 15 people. According to DA, after two years of operation, Radio Sritanjung FM decided to reduce the number of permanent employees to only seven people, and the rest are part-time workers.

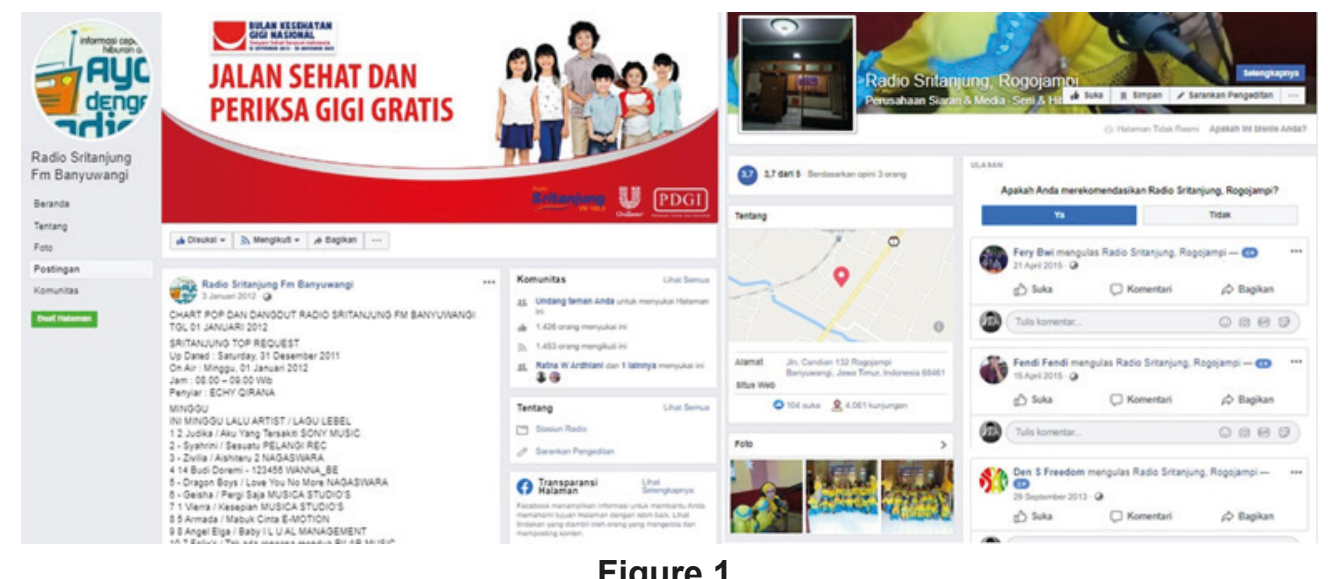

Figure 1.

Facebook account of Radio Sritanjung FM in 2005-2012 (left) and 2012-2015 (right) Source: Facebook (2020a, 2020b)

Radio Sritanjung FM initiated mediamorphosis by developing Facebook as broadcast support in 20052012 (Figure 1). This choice was not just following trends; however, an effort to follow recommendations from PRSSNI East Java. The aim was to enrich the company profile and be able to support network marketing activities. Uniquely, Radio Sritanjung FM frequently changed its Facebook account because of an error in entrusting the Facebook account password to a computer technician or office guard. When the technician or office guard stopped working, the Facebook account password did not return to management. In 2010, Radio Sritanjung FM once sent some of its employees for a comparative study to Bandung. According to LH, one goal was to learn to broadcast live streaming via Facebook on Radio Oz Bandung.

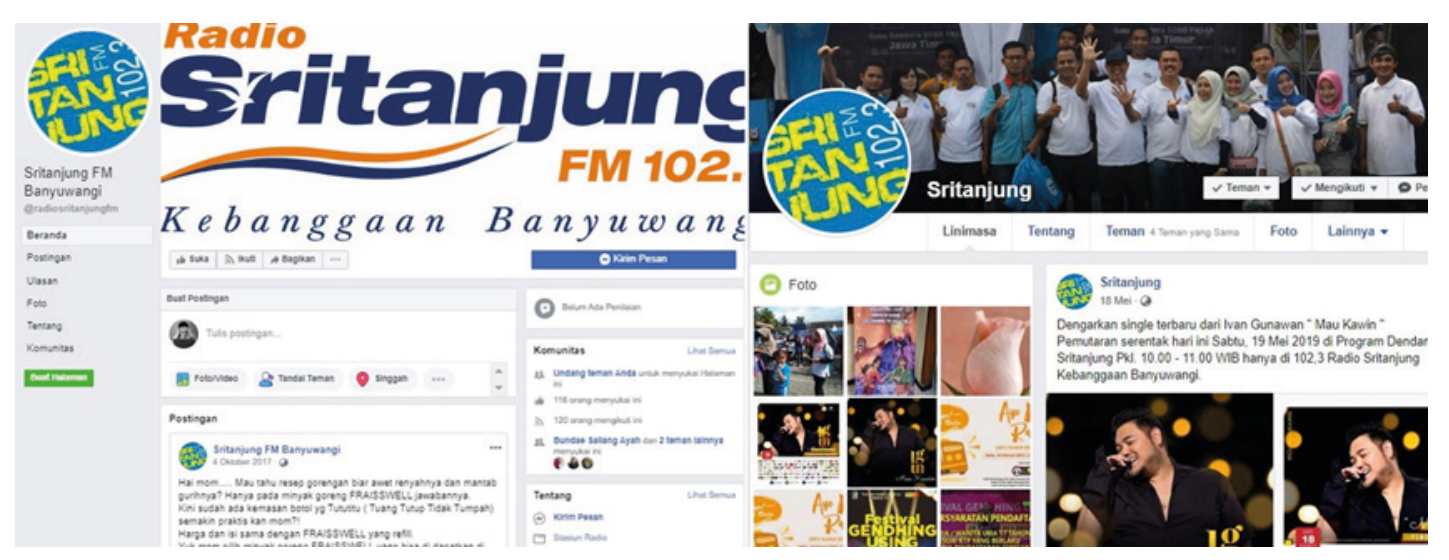

Figure 2.

Facebook account Radio Sritanjung FM in 2015-2017 (left) and 2017-now (right)

Source: Facebook (2020c, 2020d) 


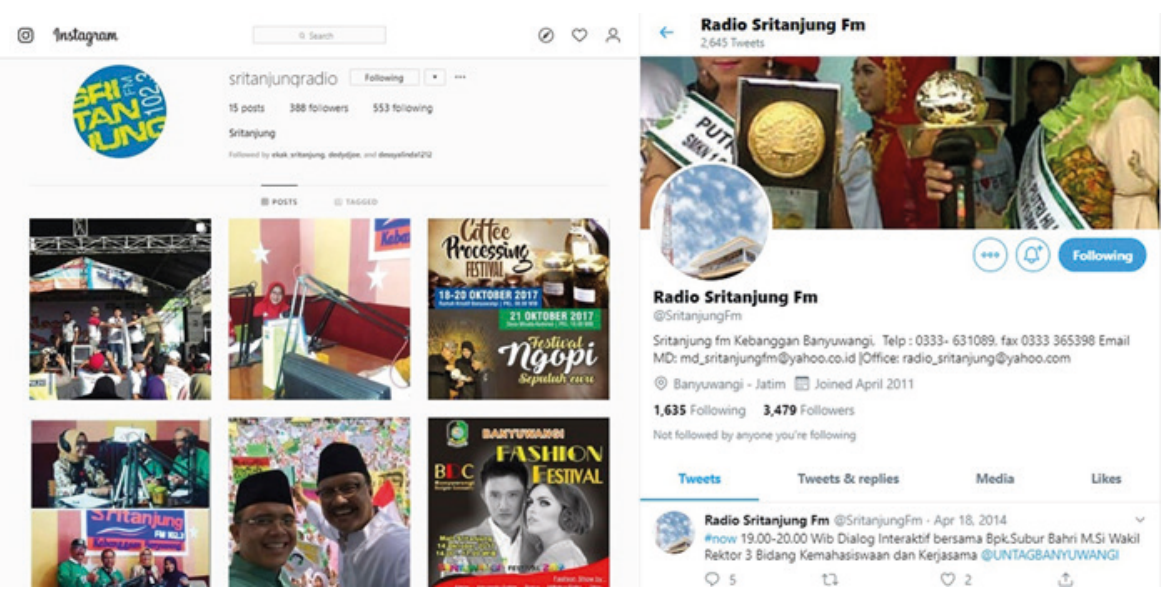

Figure 3.

Twitter account (left) and Instagram account (right) of Radio Sritanjung FM Source: Instagram (2020), Twitter (2020)

Radio Sritanjung FM has created a Facebook account four times, namely in 2005, 2012, 2015, and 2017; however, on its journey, live streaming broadcasts via Facebook on Radio Sritanjung FM only lasted until the end of 2017 because they did not get sufficient income. Then it activated again in 2019 for specific broadcast programs - especially the coverage of cultural activities (Figure 2). The management also created a Twitter account (April 2011) and Instagram account @sritanjungradio (June 2017). Those two accounts were not well-developed due to management policies that did not appoint someone with a specific role to be the administrator. The plan was that the Instagram account would integrate with a Facebook account and blog page; however, the blog creator's content failed (Figure 3).

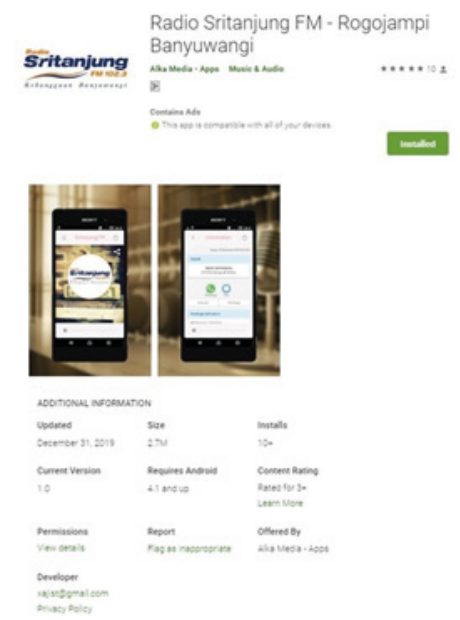

Figure 4.

Audio streaming application of Radio Sritanjung FM in Google Play

Source: Google Play (2020)

The latest technology initiation to support broadcast was the streaming audio application downloaded from Playstore (Figure 4). The official launching of this application, on 1 January 2020, coincided with the new year celebrations. Audio streaming is a technology to reduce the audio file size so that it is easy to penetrate the internet. As a broadcasting application, it is streaming audio broadcasts over an Internet Protocol (IP) basis. This way, radio broadcasts on the internet by Radio Sritanjung FM add a particular device to the radio transmitter. Therefore, listeners can enjoy radio broadcasts in real-time on the internet, although sometimes there is a delay in seconds. The initial connection speed is $96 \mathrm{kbps}$ with a minimum connection (upstream) of $100 \mathrm{kbps}$, or the estimated number of current connections is 100 real-time users. Any more than that, the sound will become choked or choppy. Radio Sritanjung FM plans to increase its streaming bit rate to $128 \mathrm{kbps}$ with an upstream connection of $200 \mathrm{kbps}$; therefore, 
the server can serve up to 200 connections, with a sound quality close to compact disc quality. According to FGD, since using audio streaming technology, Radio Sritanjung FM has broader broadcast coverage; the number of listeners has increased, expanding the opportunity to get advertisements.

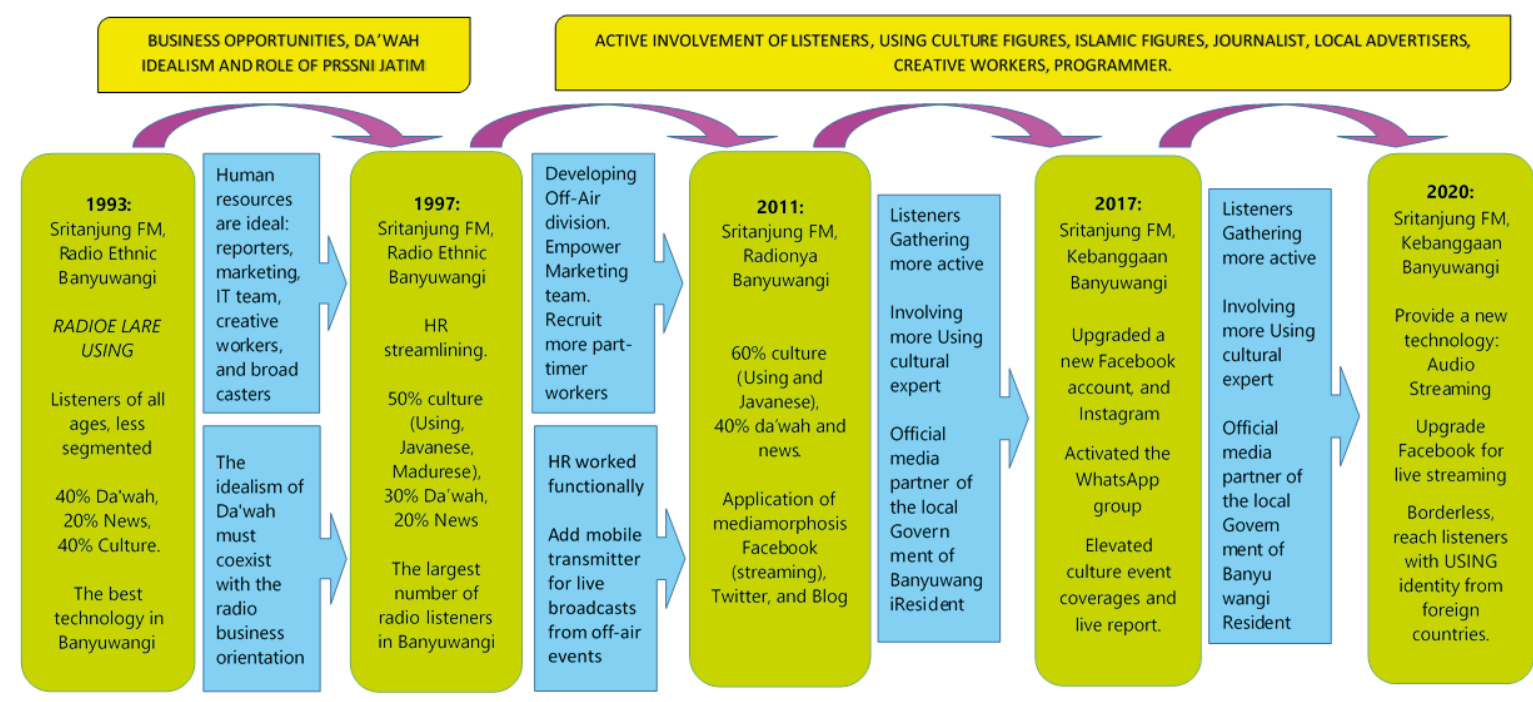

Figure 5.

History and mediamorphosis process of Radio Sritanjung FM

Source: Primary research data

The mediamorphosis process of Radio Sritanjung FM indicates a total consideration in utilizing the communication media platform on the internet. Other radio stations developed Facebook streaming in 2016 and received national advertising revenue. Radio Sritanjung FM has disabled Instagram, Twitter, and live streaming on Facebook. Only the WhatsApp group and Facebook are left because Radio Sritanjung FM targets local advertisers' revenue. Figure 5 is a chronological summary of the development of Radio Sritanjung FM and its application of mediamorphosis. During 2017 and 2018, many Banyuwangi district government events collaborated with Radio Sritanjung FM as the official media partner. These government programs' goal was to get live streaming on talk shows in the studio or off-air. According to FGD, radio marketing using the barter model is very profitable because the sponsors of these regional government-owned events also place advertisements for their products on Radio Sritanjung FM.

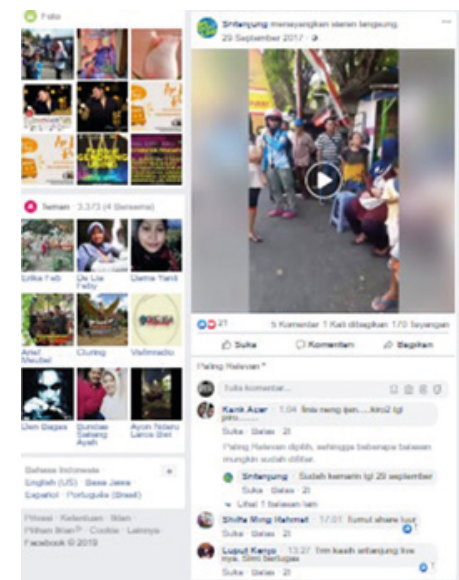

Live streaming on International Tour De Banyumangi (middle) and Banyuwangi Kuliner \& Art Week 2018 (right)

Source: Facebook (2020a) 
An essential event for the Banyuwangi people is The International Tour De Banyuwangi Ijen 2017. This event had the most significant number of Facebook accounts (500) as visitors during the two-day (Figure 6). Moreover, the highest numbers of Facebook viewers accrued during live streaming of the semifinals of the 2017 Gendhing Using Festival in Pelinggihan. One thousand six hundred seventy-one accounts were watching the event broadcast program, and it was the most viewed cultural event in Banyuwangi. Then the government entrusted Radio Sritanjung FM to broadcast live streaming at the Banyuwangi Culinary and Art Week 2018, Festival Gendhing Using 2018, and International Tour De Banyuwangi Ijen 2018 events (Figure 6).

Streaming has become in demand as listeners have replaced their transistor radio devices with smartphones. The concept of radio has shifted to a mobile application that is accessed with a different device. However, listeners are no longer passive listeners through their transistor radio devices; however, they are now volunteering to share radio content through their social networks. Listeners voluntarily upload radio-radio broadcast programs in their Facebook statuses, WhatsApp statuses, Instagram feeds, Instagram stories and share their recorded voices in the WhatsApp group.

The availability of internet technology has recognized the asymmetric power structure in the cultural radio institution. There is a hidden interest competition between radio management (directors, station managers, marketing, finance) and creative professionals (programmers, music directors, broadcasters). For creative professionals, the availability of technology is a mandatory supporting platform for their professional work. For radio management, the availability of technology is an investment and must, in return, provide financial benefits. All technologies must support revenue (financial benefits) to attract as many advertisers as possible (Achmad \& Ida 2019, Achmad 2020b, Achmad et al. 2020b).

The technological development of Radio Sritanjung FM is not too complicated regarding either the program or the cost. If it is crucial to support programmers and broadcasters' work productivity and facilitate listeners' access, the management will fulfill a precise need for technology development. The most important thing for directors is that the company remains sustainable and that its salaries are sufficient. Any technological development that has the potential to increase economic benefits will get financial support. Radio Sritanjung FM is developing technology by considering its potential for financial profit, and management is very careful about calculating expenses.

The existence of the internet and communication platforms that accommodated by digital technology provides a new form of social relationship that does not necessarily change or oppose the old social forms (Febrianita \& Kusnarto 2018, Tutiasri et al. 2019, Achmad et al. 2020a, Arviani et al. 2019, Candrasari 2019). The process of broadcasting, listening, and advertising has not changed. It is the shape and the platform that has changed (virtual).

Changing forms or delivery mechanisms have an impact on changing social relationships. The social relations do not change; however, the direction and structure are likely to change. The listener's relationship with the broadcaster has not changed; what has changed is the direction and structure. It used to be one way from broadcaster to listener without direct feedback. Now it is two-way and participatory. Radio station relations with advertisers have not changed; what has changed is the advertisements' place and form. Radio stations used to sell programs, and advertisers bought time. Now radio sells programs and digital platforms to advertise (Facebook, Twitter, YouTube, Instagram). At the same time, advertisers buy time (ad duration), type (text, photos, videos), and place (Facebook, Twitter, YouTube, Instagram) (Achmad 2019, Achmad \& Ida 2019). Seeing the broader potential for advertising justifies further investment and expansion of operations. Mediamorphosis of radio stations does not merely look at the processes and forms of convergence taking place. It must consider and movement of capital and market to capitalism's new operational areas. Mediamorphosis with media convergence provides enormous capital and market mobility (Arviani 2013, Ulfa 2016, Trinoviana 2017). 
Convergence is often considered a technology-driven phenomenon; however, it is not just about shifting technology; fundamentally, convergence is a change in the relationship between technology, industry, markets, and audiences (Jenkins 2006, Jin 2012, Evens 2014). In the global media industry, convergence is the commercial integration between media content companies, such as television and radio networks, and transmission lines, such as telephone cable networks. Therefore, media convergence is consolidation through industry alliances and mergers, a combination of technology and network platforms, and integration between services and markets (Baldwin et al. 1996, Jin 2013). Media convergence, in other words, is the integration of the functions of various media into one increasingly sophisticated media (Brereton 2004, Flew 2005, Storsul \& Fagerjord 2010, Achmad 2020a).

By its very nature, radio has a loyal listener or fan base, and its auditory nature makes radio last for all time (O’Neill 2007, Cordeiro 2012). As evidenced from Nielsen's (2016) Radio Audience Measurement (RAM) data, radio is one of the conventional media that will continue to exist in the future. Nielsen (2016) conducted a radio measurement survey in eleven major cities in Indonesia, namely: Medan, Palembang, Bandung, Jakarta, Semarang, Jogjakarta, Surabaya, Surakarta, Denpasar, Banjarmasin, and Makassar. From September to December 2016, 57\% of Indonesian radio listeners comprised 19\% Generation Z (10-14 years) and 38\% Millennials (15-34 years). There are still many who like radio media, and it can undoubtedly survive into the future because radio has young future consumers. Other data show that the radio penetration rate is in fourth place at 38\%, after television media (96\%), outdoor media (52\%), and the internet (40\%). Around 20 million people of Indonesia's total population listen to the radio, with an average listening time of 139 minutes per day or 16 hours 18 minutes per week (Nielsen 2016).

By utilizing the internet as various virtual spaces to support its broadcasts, Radio Sritanjung FM mediamorphosis applies the basic principles: coevolution and coexistence, inheritance, survival, opportunities, and needs, and delayed adoption (Fidler 1997, Tomasello et al. 2010). The new way of broadcasting via Facebook live streaming and audio streaming via mobile phones shows that Radio Sritanjung FM experiences coevolution and coexistence. That is, it is in the process of developing toward a complex and adaptive way of broadcasting. Radio Sritanjung FM, which used to rely on the power of transmitters and high towers to disseminate and sell program content, is now adapting by adding computers, the internet, Facebook, Instagram, Twitter, and audio streaming applications to broadcast.

The use of local language as an introduction to broadcast proves the truth of the principle of inheritance. Although Radio Sritanjung FM has been broadcasting using new forms on Facebook, Instagram, Twitter, and audio streaming, they have retained the local language as the medium of broadcast. The element of communication inherited in this new form is language. When adding ways to communicate and interact with listeners via WhatsApp groups and comments on Facebook, Radio Sritanjung FM demonstrated its ability to survive by maintaining its listeners' loyalty by adapting digital communication technology. The media must immediately follow media audiences who are already in the virtual world. Because maintaining the loyalty of radio listeners is an attempt to maintain a relationship of mutual need (Fidler 1997, Achmad 2020a).

\section{Conclusion}

Radio Sritanjung FM has been implementing mediamorphosis since 2011 with Facebook, Twitter, Instagram, and Web blog. The latest technology applied is audio streaming on cellular phones with the Android operating system. During the COVID-19 pandemic, mediamorphosis is a means of encouragement to disseminate, promote, and pass down the Using-ethnic culture to the Banyuwangi community and foreign countries. In producing Using-ethnic cultural programs, management involves loyal listeners, Using-ethnic figures, Muslim leaders, local journalists, and local advertisers. Especially in the COVID-19 pandemic, the management held discussions with these parties for making programs and designing advertisements. Radio Sritanjung FM positions the parties as producers of radio programs and advertisements. The broadcast of the Using-ethnic cultural program on Radio Sritanjung FM has 
become the pride of Banyuwangi residents and has become a representation of the Using-ethnic identity spread across Indonesia and abroad. Pride in local identity is part of the diversity of Indonesia's national identity.

\section{Acknowledgement}

The authors would like to thank the Head of LPPM UPN Veteran East Java, Dr. Ir. Yenny Wuryandari, MP., Dean of FISIP UPN Veteran East Java, Dr. Drs. Ec. Gendut Sukarno, MS., CHRA, Lemhannas Alumni Association, East Java Province Commissariat; UPN Television; Committee of Konferensi Media Digital (KOMEDI Mentionage 2020), and reviewers.

\section{References}

Achmad ZA (2019) Integrasi program dakwah dan budaya: Studi etnografi virtual mediamorfosis Radio Nada FM Sumenep Madura. Jurnal Komunikasi Islam 9 (2):238-263. https://doi.org/10.15642/ jki.2019.9.2.238-263.

Achmad ZA (2020a) Mediamorphosis: Understanding New Media by Roger Fidler, Thousand Oaks, California: Pine Forge Press (2003). In: Nawangsari ER \& Kriswibowo A (ed). Potret Masyarakat dan Kebijakan Pemerintah dalam Menghadapi Tantangan Pandemi COVID-19. Surabaya: Program Studi Ilmu Administrasi Negara, UPN “Veteran” Jawa Timur.

Achmad ZA (2020b) Pergeseran relasi antara pendengar radio dengan institusi radio dalam masyarakat jaringan (Studi etnografi virtual pada radio-radio budaya di Jawa Timur yang bermediamorfosis). Dissertation, Universitas Airlangga, Surabaya.

Achmad ZA \& Ida R (2018) Etnografi virtual sebagai teknik pengumpulan data dan metode penelitian. The Journal of Society and Media 2 (2):130-145. https://doi.org/10.26740/jsm.v2n2.p130-145.

Achmad ZA \& Ida R (2019) The shifting role of the listeners in the mediamorphosis process of culture radio: A case study of Jodhipati 106.1 FM. Masyarakat, Kebudayaan dan Politik 32 (3):240-250. https://doi.org/10.20473/mkp.v32i32019.240-250.

Achmad ZA, Azhari TZ, Esfandiar WN, Nuryaningrum N, Syifana AFD, \& Cahyaningrum I (2020a) Pemanfaatan media sosial dalam pemasaran produk UMKM di Kelurahan Sidokumpul, Kabupaten Gresik. Jurnal Ilmu Komunikasi 10 (1):17-31. https://doi.org/10.15642/ jik.2020.10.1.17-31.

Achmad ZA, Juwito J, \& Saud M (2020b) The local creative ads on Sritanjung FM to increase financial revenue during COVID-19 pandemic. Bricolage: Jurnal Magister Ilmu Komunikasi 6 (2):135249. https://doi.org/10.30813/bricolage.v6i02.2229.

Achmad ZA, Arviani H, \& Santoso NR (2021) The Sanak-Kadang Jodhipati: A new form of virtual radio listeners community. Jurnal Aspikom 6 (1):94-109. https://doi.org/10.24329/aspikom. v6i1.830.

Alamiyah SS \& Achmad ZA (2015) The role of citizen journalism in creating public sphere in indonesia. In: International Conference on Democracy and Accountability (ICoDA), 10 November, Surabaya. Surabaya: Fakultas Ilmu Sosial dan Ilmu Politik Universitas Airlangga. 162-167.

Arviani H (2013) Budaya global dalam industri budaya: Tinjauan madzhab Frankfurt terhadap iklan, pop culture, dan industri hiburan. Global \& Policy: Journal of International Relations 1 (2):130141.

Arviani H, Prasetyo GS, \& Walgunadi VV (2019) Instagram and millennial generation:\#Explorebanyuwangi analysis. In: 2nd International Media Conference 2019 (IMC 2019), 7-8 November, Surabaya.

Baldwin TF, McVoy DS, \& Steinfield C (1996) Convergence: Integrating Media, Information, and Communication. California: SAGE.

Barber S (2010) Smooth jazz: A case study in the relationships between commercial radio formats, audience research and music production. Radio Journal: International Studies in Broadcast and Audio Media 8 (1):51-70. https://doi.org/10.1386/rjao.8.1.51_1.

Benkler Y (2006) The Wealth of Networks: How Social Production Transform Markets and Freedom. New Haven \& London: Yale University Press.

Biagi S (2017) Media/Impact: An Introduction to Mass Media (12th ed). Boston: Cengage Learning. 
Bonini T (2014) The new role of radio and its public in the age of social network sites. First Monday 19 (6). https://doi.org/10.5210/fm.v19i6.4311.

Bonini T \& Monclús B (ed) (2015) Radio Audiences and Participation in the Age of Network Society. New York: Routledge.

Bosch TE (2014) Commercial music radio, race and identity in South Africa. Media, Culture and Society 36 (7):901-915. https://doi.org/10.1177\%2F0163443714536076.

Brereton P (2004) Reviews: Andrew Murphie and John Potts, culture and technology. Convergence: The International Journal of Research into New Media Technologies 10 (2):117-119. https://doi. org $/ 10.1177 / 135485650401000208$.

Candrasari Y (2019) Mediated interpersonal communication: A new way of social interaction in the Digital Age. In: 2nd International Media Conference 2019 (IMC 2019), 7-8 November, Surabaya.

Castells M (2010) The Rise of the Network Society. Chicester, West Sussex: Wiley-Blackwell.

Clandinin DJ \& Connelly FM (2004) Narrative Inquiry: Experience and Story in Qualitative Research. London: Wiley-Blackwell.

Commercial Radio Australia (2004) Commercial radio-a snapshot. [Accessed 17 September 2020]. http://www.radioalive.com.au/RIALT/media/RIALT/Audio/CRA_a_Snapshot.pdf?ext=.pdf.

Cordeiro P (2012) From radio to R@dio: Broadcasting in the 21st century. In: Radio Conference Proceedings, 14-16 September, Braga.

Evens T (2014) (De)convergence in TV: A comparative analysis of the development of Smart TV. In: European Media Management Association (EMMA) Conference, 12-13 June, Tallinn.

Facebook (2020a) Radio Sritanjung FM Banyuwangi. [Accessed 20 August 2020]. https://www. facebook.com/Radio-Sritanjung-Fm-Banyuwangi-198327080239695/.

Facebook (2020b) Radio Sritanjung, Rogojampi. [Accessed 20 August 2020]. https://www.facebook. com/pages/ Radio-Sritanjung-Rogojampi/240485955988766.

Facebook (2020c) Sritanjung. [Accessed 20 August 2020]. https://www.facebook.com/profile. php?id=100010926105561.

Facebook (2020d) Sritanjung FM Banyuwangi. [Accessed 20 August 2020]. https://www.facebook. com/radiosritanjungfm.

Febrianita R \& Kusnarto K (2018) The internet addiction: Challlenges to conflict settlement in family communication. Dinamika Administrasi: Jurnal Ilmu Administrasi dan Manajemen 1 (1):70-79.

Ferguson F (2007) What Can I Do Now? Exploring Careers for Your Future: Radio and Television (2nd ed). New York: Infobase Publishing.

Fidler R (1997) Mediamorphosis: Understanding New Media. California: Pine Forge Press.

Flew T (2005) New Media: An Introduction. Oxford: Oxford University Press.

Gauntlett D (2000) Web.Studies: Rewiring Media Studies for the Digital Age. London: Hodder Education Publishers.

Google Play (2020) Radio Sritanjung FM - Rogojampi Banyuwangi. [Accessed 2 September 2020]. https://play.google.com/store/apps/details?id=com.xajist.sritanjungfm.

Hadadi K \& Almsafir MK (2013) The Relationship between media advertising and selling ratios: A Review Paper. Journal of Modern Marketing Research 2 (1):86-97.

Hair N \& Clark M (2003) An Enhanced Virtual Ethnography: The Role of Critical Theory Stream 5: Exploring the Meaning of 'Critique' in Electronically-Mediated Work. Bedforshire: Cranfield University.

Halbrooks G (2018) What are radio formats? Definition \& examples of radio formats. The Balance Careers. [Accessed 28 August 2020]. https://www.thebalancecareers.com/what-are-radioformats-and-why-do-they-matter-2315430.

Hine C (2000) Virtual Ethnography. London: Sage Publications Ltd.

Hine C (2005) Virtual Methods: Issues in Social Research on the Internet. Oxford: Berg.

Hine C (2008) How Can Qualitative Internet Researchers Define the Boundaries of Their Projects? In: Markham A \& Baym N (ed). Internet Inquiry: Conversations About Method. Los Angeles: SAGE.

Hine C (2017) Virtual Ethnography: Modes, Varieties, Affordances. In: Fielding N et al. (ed). The SAGE Handbook of Online Research Methods. Los Angeles: SAGE. 
Horn S (1998) Cyberville: Clicks, Culture, and the Creation of an Online Town. New York: Warner Books.

International IDEA (2020) Adapting to the New Normal: Political Parties during Lockdown and Social Distancing. Stockholm: International Institute for Democracy and Electoral Assistance.

Instagram (2020) Sritanjung. [Accessed 2 September 2020]. https://www.instagram.com/sritanjungradio/. Jaekel B (2017) Radio broadcasters see uptick in ad revenue on location-based targeting. Marketing Dive, 23 July. [Accessed 20 November 2020]. https://www.marketingdive.com/ex/mobilemarketer/ $\mathrm{cms} /$ news/advertising/20939.html.

Jenkins H (2006) Convergence Culture: Where Old and New Media Collide. New York \& London: New York University Press.

Jin DY (2012) The new-wave of de-convergence: A new business model of the communication industry in the 21 Century. Media, Culture, Society 34 (6):761-772.

Jin DY (2013) De-Convergence of Global Media Industries. New York: Routledge.

Kendall L (1999) Recontextualizing "Cyberspace": Methodological Considerations for on-Line Research. In: Jones S (ed). Doing Internet Research: Critical Issues and Methods for Examining the Net. United States: SAGE Publications.

Kimms A \& Muller-Bungart M (2007) Revenue management for broadcasting commercials: The channel's problem of selecting and scheduling the advertisements to be aired. International Journal of Revenue Management 1 (1):28. https://doi.org/10.1504/IJRM.2007.011192.s.

King G (2015) Hearing community radio listeners: A storytelling approach for community media audience research. Participations: Journal of Audience and Reception Studies 12 (2):121-136.

Lee P, Stewart D, Loucks J, \& Arkenberg C (2018) Radio: Revenue, reach, and resilience. Deloitte, 11 December. [Accessed 8 February 2020]. https://www2.deloitte.com/us/en/insights/industry/ technology/technology-media-and-telecom-predictions/radio-revenue.html.

May A (2013) Why radio is still relevant in a digital age. Just Media, 9 August. [Accessed 17 November 2020]. https://justmedia.com/2013/08/why-radio-is-still-relevant-in-a-digital-age/.

McFadden JB (2012) Understanding Media and Culture: An Introduction to Mass Communication. Minnesota: University of Minnesota.

Meyer G \& Thomas J (1990) The Baudy World of the Byte Bandit: A Postmodernist Interpretation of the Computer Underground. In: Schmalleger F (ed). Computers in Criminal Justice: Issues and Applications. Bristol: Wyndham Hall Press.

Miles MB, Huberman AM, \& Saldana J (2014) Qualitative Data Analysis a Methods Sourcebook (3 ${ }^{\text {rd }}$ ed). USA: Sage Publications.

Morello R (2019) How do radio stations make a profit? Chron, 28 January. [Accessed 8 May 2020]. http://smallbusiness.chron.com/radio-stations-make-profit-57480.html.

Mursidi A \& Soetopo D (2018) Toponimi Kecamatan Kabupaten Banyuwangi: Pendekatan Historis. Banyuwangi: LPPM Universitas PGRI Banyuwangi.

Myers D (1987) Anonymity is part of the magic: Individual manipulation of computer-mediated communication contexts. Qualitative Sociology 10 (3):251-266.https://doi.org/10.1007/BF00988989.

Mytton G (1992) Handbook on Radio and Television Audience Research. London: International Broadcasting Audience Research BBC World Service.

Nielsen NV (2016) Radio masih memiliki tempat di hati pendengarnya (press release). [Accessed 17 November 2020]. https://www.nielsen.com/id/en/press-releases/2016/radio-masih-memilikitempat-di-hati-pendengarnya/.

Nguyen TTT (2008) The role of radio and tv in the life of ethnic minorities in Vietnam (Case study: The H'Mong people in Lao Cai and Lai Chau Province). Thesis, University of Tromsø, Tromsø.

Nwammuo AN (2011) Mediamorphosis: Analyzing the convergence of digital media forms alongside African traditional media. African Journals Online 5 (2):115-125. https://doi.org/10.4314/afrrev. v5i2.67309.

Ofcom (2006) Radio advertising market research: Assessment of the constraints on the price of direct and indirect radio advertising. Research Report. London: Office of Communications, UK. [Accessed 29 August 2020]. https://www.ofcom.org.uk/_data/assets/pdf_file/0013/24070/research.pdf. 
O'Neill B (2007) Digital technologies and the future of radio: Lessons from the Canadian experience. In: The Radio Conference: A Transnational Forum, 16-19 July, Lincoln.

Pandey S, Dutta G, \& Joshi H (2017) Survey on revenue management in media and broadcasting. Informs Journal on Applied Analytics 47 (3):195-213. https://doi.org/10.1287/inte.2017.0886.

PRSSNI (2018) Profil Anggota Persatuan Radio Siaran Swasta Nasional Indonesia Jawa Timur. [Accessed 29 August 2020]. https://www.radiojatim.com/index.php?option=com_conte nt\&view $=$ article\&id $=3 \&$ Itemid $=188$.

Reid EM (1992) Electropolis: Communication and community on internet relay chat. Thesis, University of Melbourne, Melbourne.

Rheingold H (1995) The Virtual Community: Finding Connection in a Computerized World. London: Minerva Press.

Rothenbuhler EW (1996) Commercial radio as communication. Journal of Communication 46 (1):125143. https://doi.org/10.1111/j.1460-2466.1996.tb01464.x.

Sharf BF (1999) Beyond Netiquette: The Ethics of Doing Naturalistic Discourse Research on the Internet. In: Jones S (ed). Doing Internet Research: Critical Issues and Methods for Examining the Net. United States: SAGE Publications.

Shauma A \& Achmad ZA (2015) Efektivitas iklan politik di televisi (Studi deskriptif kuantitatif efektifitas iklan politik Aburizal Bakrie versi motivasi anak Indonesia pada pemilih pemula di Surabaya). Jurnal Imu Komunikasi 7 (2):1-10.

Shumar W \& Madison N (2013) Ethnography in a virtual world. Ethnography Education 8 (2):255-272. https://doi.org/10.1080/17457823.2013.792513.

Sterling CH \& Kittross JM (2002) Stay Tuned: A History of American Broadcasting ( $3^{\text {rd }}$ ed). New Jersey: Lawrence Erlbaum Associates.

Storsul T \& Fagerjord A (2010) Digitization and Media Convergence. In: The International Encyclopedia of Communication. Chichester: John Wiley \& Sons.

Tjahjo JDW (2012) Studi ekonomi media tentang pengaruh jenis acara dan jangkauan siaran terhadap jumlah pendengar dan keuntungan perusahaan pada industri jasa radio siaran di wilayah Gerbangkertosusila. Dissertation, Universitas Airlangga, Surabaya.

Tomasello TK, Lee Y, \& Baer AP (2010) "New media" research publication trends and outlets in communication, 1990-2006. New Media \& Society 12 (4):531-548.

Trinoviana A (2017) Strategi konvergensi radio sebagai upaya perluasan pasar audience dan iklan (Studi kasus pada Swaragama FM (101.7 FM), Geronimo FM (106.1 FM), dan Prambors Radio (102.2 FM/95.8 FM)). Jurnal Komunikasi 12 (1):35-50. https://doi.org/10.20885/komunikasi.vol12.iss1. art3.

Turkle S (2011) Life on the Screen: Identity in the Age of the Internet. New York: Simon \& Schuster.

Tutiasri RP, Kusuma A, \& Sumardjijati S (2019) Perilaku remaja dalam penyebaran hoax di grup WhatsApp. Jurnal Ilmu Komunikasi 2 (1):36-43. https://doi.org/10.33005/jkom.v2i1.36.

Twitter (2020) Radio Sritanjung FM. [Accessed 21 August 2020]. https://twitter.com/sritanjungfm.

Ulfa EM (2016) Strategi radio untuk membangun masyarakat berjaringan studi kasus penggunaan sosial media di Suara Surabaya Media. Jurnal Pekommas 1 (2):207-220. https://doi.org/10.30818/ jpkm.2016.2010210.

Walker J (2004) Rebels on the Air: An Alternative History of Radio in America (2 ${ }^{\text {nd }}$ ed). New York: New York University Press.

Warren S (2005) Radio: The Book (4 ${ }^{\text {th }}$ ed). Burlington: Elsevier Focal Press.

Wilkinson C (2015) Young people, community radio and urban life. Geography Compass. 9 (3):127139. https://doi.org/10.1111/gec3.12197.

Wulandari R (2018) Kehidupan sosial budaya masyarakat Using di Desa Aliyan Kecamatan Rogojampi Kabupaten Banyuwangi Tahun 1940-2017. Thesis, Universitas Jember, Jember. 